\title{
Putting the Child Reader First: The Croatian Translation of J.R.R. Tolkien's Father Christmas Letters
}

\section{Abstract}

The paper analyzes the Croatian translation of a collection of J.R.R. Tolkien's letters to his children - the posthumously published Father Christmas Letters (1976). Situated within the theoretical and methodological framework of descriptive translation studies, the paper will examine specific translation strategies and tactics utilized to make the text more comprehensible and accessible to the target (child) audience, thus demonstrating that the translator, Zlatko Crnković, is first and foremost translating for children. The analysis is focused on the level of content (with special emphasis on culture-specific items) and style. By examining one of Tolkien's "minor" works and its translation into a "minor" language, the paper aims to address underscrutinized areas within Tolkien, translation, and children's literature studies ${ }^{[1]}$

Keywords: children's literature, Father Christmas Letters, J.R.R. Tolkien, Pisma Djeda Božićnjaka, translation strategies

\section{Introduction}

In her article on Romanian translations of Beatrix Potter's The Tale of Peter Rabbit, Dana Cocargeanu points to the low visibility of Romanian children's literature - especially literature in translation - in international scholarship as one of the main stimuli for her research. A similar case can be made for Croatian children's literature, which - with some rare but notable exceptions such as the works of four-time Nobel Prize nominee Ivana Brlić-Mažuranić (1874-1938; cf. Zima)[2] _ 
remains largely overlooked within the international context. Translations for children fare ever worse as they are overlooked even within Croatian scholarship. Recent years have seen a gradual shift in this trend, with translations of Croatian children's literature into foreign languages (e.g. Haramija; Machata; Narančić Kovač; Šmidt Pelajić) attracting an increasing interest. However, the same cannot be said of the translations of international children's literature into Croatian, which, while not entirely lacking scholarly attention (some exceptions include Narančić Kovač and Milković; Zalar), remain insufficiently scrutinized.

The present paper proposes to address this gap by examining the translation of J.R.R. Tolkien's Father Christmas Letters (published posthumously in 1976; henceforth FCL) into Croatian (Pisma Djeda Božićnjaka, 2002; henceforth, PDB) ${ }^{[3]}$ Following the definition proposed by Jeremy Munday, the term translation is understood within this paper as the process of "changing an original written language (source language) into a written text (target text) in a different verbal language (target language)" (5).

While Tolkien's oeuvre has been the subject of extensive research, it should be noted that the growing body of scholarship on the British writer and linguist has so far been almost exclusively focused on texts dealing with the fictional realm of Middle-earth, primarily The Hobbit (1937), The Lord of the Rings trilogy (1955; henceforth LOTR), and The Silmarillion (published posthumously in 1977). Popularly termed Tolkien's "minor" works (cf. Artamonova), the non-Middle-earth writings (and especially their translations) ${ }^{[4]}$, particularly those intended for children ${ }^{[5]}$, present an underresearched area within Tolkien studies. By studying one such "minor" work and its translation into a "minor" language, the present paper proposes to contribute to both Tolkien studies and the study of translations of children's literature.

Situated within the theoretical and methodological framework of translation studies, specifically descriptive translation studies (cf. Toury), the present paper aims to identify dominant translation strategies (meaning an overall translation procedure or program; Gambier 413) and tactics (meaning specific actions and techniques by which strategies are achieved; Gambier 413) utilized in the Croatian translation of the FCL, and determine whether or not their choice is predicated on the identity of the intended, child reader. The analysis is modeled after the existing research on 
translations of children's literature, primarily the works of Gillian Lathey and Riitta Oittinen ( Translating for Children).

The first part of the paper introduces the FCL, views it within the body of Tolkien's "minor" works, and provides an overview of the existing research on the book. A brief introduction to PDB is followed by its analysis, which constitutes the main part of the paper. The analysis relies on the assumption that the translator's choice of specific strategies and tactics is guided by his perception of the target child readers - more specifically, their perceived interests and levels of (general) knowledge, literacy, and comprehension. The analysis will specifically focus on the stylistic and the level of content. Given the amount of culture-specific information conveyed by the source text (ST) - especially those pertaining to Christmas customs and traditions - special attention within the analysis of content will be devoted to the treatment of culture-specific items (CSIs), defined as elements of the source culture (SC) which do not have an equivalent in the target culture (TC; Franco Aixelá 58), such as customs, units of measurement, and names. The concluding part provides a summary of the main findings as well as tentative guidelines for future research.

\section{The Corpus}

\section{1. "Love from Father Christmas": About the Letters}

Christmas holidays are a prominent event in the lives of many children. However, the children of J.R.R. Tolkien had even more reasons to look forward to the season of giving as they received personal annual epistles from none other than Father Christmas himself. For more than twenty years (1920-1943), handwritten and ornately illustrated letters (penned and illustrated, of course, by Tolkien himself) bearing news of life on the North Pole found their way to the Tolkien household. Assuming the guise of Father Christmas, the writer went to great lengths to create an impression of authenticity: not only were the letters written in shaky handwriting and richly illustrated, but the envelopes also bore the stamp and postal mark of the North Pole. Much thought and care were put even into the way in which the letters were delivered: "[S]ometimes by Father Christmas himself (a snowy footprint having been left behind) or by the local postman (in league with the children's parents)" (Hyde 23). 
The correspondence was prompted by an inquiry made by Tolkien's three-year-old son John, who wanted to know what Father Christmas was like and where he lived. In response, a letter from the North Pole arrived (bearing the date December 22, 1920), addressed to John personally (Scull and Hammond 297). As the years went by, brief communications about Father Christmas's busy schedule and various gift-related matters gradually became lengthier and more complex, delivering an increasing amount of details about the North Pole household - which, in addition to Father Christmas, includes his helper, the clumsy but well-meaning North Polar Bear, the gardener SnowMan, the elf secretary Ilbereth, etc. - and its many adventures.

Individual letters typically describe some misfortune that befalls Father Christmas during the gift preparation period, usually caused by the Polar Bear (as Father Christmas himself notes in a letter from 1931, "I should hardly feel it was Christmas if he didn't do something ridiculous"; Tolkien, FCL 19), such as the destruction of Father Christmas's house, the accident with the Northern Lights, the flood caused by water overflowing from the sleeping Polar Bear's bathtub, battles with goblins, etc. In addition to the reports on the more mundane aspects of life on the North Pole (cf. Swank 130), the letters contain answers to the questions posed by the Tolkien children in their own communications as well as references to contemporary events (most notably World War II).

Published on the third anniversary of Tolkien's death (September 2, 1976) by Allen and Unwin and edited by Baillie Tolkien, the FCL contain "only a few examples" (Tolkien, FCL 5) of the rich correspondence received by the Tolkien children. What is more, the letters appear in a more or less abridged form: they all lack both the "header" (the North Pole address, greeting, full date) and, in the majority of cases, "footer" (farewells), and some have also been shortened (omissions typically include personal communications and/or answers to the comments and questions posed in the children's letters). A second, American edition, published by Houghton Mifflin, followed in October of the same year. It was not until 1999 that a complete edition, entitled Letters from Father Christmas (henceforth LFC) appeared, containing previously unpublished letters as well as additional illustrations and reproductions of envelopes. New, even further expanded editions of the LFC followed in 2009 and 2012[6]

\subsection{Overview of Literature}


Tolkien's non-Middle-earth books - among them the FCL - have so far remained on the margins of Tolkien scholarship ${ }^{7]}$, rarely studied for their own sake and more as glimpses into the author's creative process and sources for examining the origins of the characters, themes, and motifs typical of his legendarium (Artamonova 190). Janet Croft, for instance, concludes her overview of Tolkien's writings for children by stating that "[f]or anyone with a more than casual interest in Tolkien as a writer, they shed invaluable light on his creative process, his family relations, and the themes that underlie all his writing," thus offering important insight into the "maturation of [his] skill at creating a coherent fantasy world" (70). This is also true of the FCL, which has almost exclusively been studied in relation to the Middle-earth writings. The links between this book and Tolkien's "major" works are identified even by its first reviews: writing for the Times Literary Supplement, Derek Brewer comments on the similarities between the FCL and LOTR, describing Father Christmas as "a proto-Gandalf" of sorts (1239). In their review of the book, Martha and Laurence Krieg identify several motifs and themes prominently featured in Tolkien's oeuvre, such as the struggle between good and evil, the presence of goblins and elves, and the use of invented languages and alphabets.

Scholarly writings on the subject have, to a large extent, followed a similar path of inquiry. Kris Swank, for example, studies the links between The Hobbit and the FCL, demonstrating how "each one influenced the development of the other - if only in small ways - and ... was also influenced by Tolkien's personal legendarium" (129). The article further identifies a series of narrative elements shared by the two books, such as the presence of elves and goblins, the inclusion of invented languages, similar episodes and plots (e.g. the Polar Bear/Bilbo getting lost in a cave), characters (Beorn/Polar Bear, Gandalf/Father Christmas), episodic narrative structure, etc. In addition to studying the FCL in relation to Tolkien's other writings (see also, e.g. Atherton; Bador), scholarly explorations of the book have, for the most part, focused on its linguistic aspects, especially the use of the "Arctic" language and its relationship to the Elvish language Quenya (cf. Hostetter; Hyde). Gerard Hynes mentions references to the continental drift in the FCL in his discussion of Tolkien's interest in tectonic movements and geology, while Michael Organ points to several illustrations and one stamp reproduced in the LFC as examples of Japanese influences on Tolkien. 


\subsection{Pisma Djeda Božićnjaka}

The Croatian translation of the FCL - the work of the renowned translator and editor Zlatko Crnković (1931-2013) - was published by the Zagreb-based publishing house Algoritam in 2002, under the title Pisma Djeda Božićnjaka. Interestingly enough, the translation is based on the FCL rather than the more recent and comprehensive LFC, nowadays considered to be the book's definitive edition. Appearing during the holiday season, the book was marketed as "the most beautiful Christmas present" for children (tagline featured on the back cover). The front cover of PDB is almost identical to that of the original (the Allen \& Unwin edition), distinguished only by the Croatian title and publisher logo found at the bottom of the page. The translator's name is absent from the front page and featured only on the copyright page and back cover.

PDB is not only a full translation of the English original (in the sense that nothing has been added or omitted) but also its faithful copy in the sense that all visual materials have been reproduced in more or less the same order and size as in the ST, with the design mirroring that of the original. Both books encompass 46 unnumbered pages. However, the intraiconic text (cf. Nikolajeva and Scott), presented in handwritten fashion, is not translated. This seems unusual since the illustrations are more than mere decorative elements: the narrative frequently mentions them and at times even purposefully omits certain information, urging the reader to consult the pictures instead. For instance, in the 1933 letter, Father Christmas substitutes a lengthy description of the events on the morning of the goblin war with a picture: "It would take too long to describe, so I have tried to draw a picture of what I saw" (Tolkien, FCL 28). The decision not to translate the intraiconic text may perhaps be ascribed to technical requirements, such as the difficulties entailed in reproducing the handwritten cursive style of the original. This notion is supported by the fact that in the few cases when "handwritten" parts of the book are translated (signatures and farewell greetings), the "handwritten" original is retained and simply accompanied by the translation, printed in "plain" text.

\section{Between Foreignization and Domestication: Translating the FCL into Croatian}


According to Lawrence Venuti, "[t]ranslation can be considered the communication of a foreign text, but it is always a communication limited by its address to a specific reading audience" (19). As numerous scholars have already noted, the question of audience is especially prominent when it comes to translating children's literature (e.g. Oittinen, Translating for Children; Reiss). Whether consciously or unconsciously, translators of children's literature are largely guided by their own notions of childhood (Oittinen, "No Innocent Act" 43) as well as by what they perceive to be the specific literary tastes and abilities (e.g. level of literacy and/or comprehension) of their target readership (Van Coillie 132-33). The influence of the intended reader on the translation process has prompted some scholars to abandon the term "translating children's literature" in favor of one which better reflects the importance of the readership: "translating literature for children" (Oittinen, "No Innocent Act"; Pascua-Febles).

As the following analysis aims to demonstrate, in PDB Crnković is also translating for children: his choices of translation strategies, individual words, and sentence structures are all guided by the perceived needs, interests, and comprehension level of his (child) readership. The analysis will examine Crnković's translation at the level of content and style. Within the discussion of content, special emphasis will be placed on CSIs, specifically holiday traditions, units of measurement, and names. When citing examples from the source and target texts, a back translation (cf. Weaver) of the Croatian translation will also be provided. It should be noted that back translations are not intended to demonstrate the translator's "(in)fidelity" to the ST, but simply to make the linguistic nuances of the translation accessible to non-Croatian speakers.

When it comes to the choice between the two main strategies identified by Lawrence Venuti, domestication (substitution or compensation of foreign elements with their equivalents in the TC) and foreignization (retaining foreign elements from the SC), the translator's concern for the child audience suggests a strong inclination towards the former. However, the specific nature of the text - letters explicitly addressed to specific readers (Tolkien's children), living at a very specific time (mid-20th century) and place (Britain) - prevents it from being fully domesticated, i.e. transplanted into a new, Croatian context. In other words, the text must inevitably retain its "foreign" flavor at least to some degree. The recognition of this fact is perhaps most evident in the translator's decision not to supplant the language of communication, identified in the original as English, with 
Croatian. Thus, when the Polar Bear apologizes for "his bad English spelling" (Tolkien, FCL 44) in the ST, the target text (TT) retains the reference to the English language.

Throughout the text Crnković shifts between foreignization and domestication, substituting some CSIs (e.g. units of measurement) with their TC equivalents (in a process Klingberg terms "cultural context adaptation" [17]), while retaining others in their original form. However, when retaining foreign elements, the translator typically (perhaps fearing that children will be put off by their unfamiliarity; Lathey 37 ) weaves their explanations into the narrative. The majority of these intratextual glosses, intended to make the text more comprehensible to target audiences (Franco Aixelá 62-63), contain information related to various Christmas customs.

\subsection{Holiday Traditions}

While most Croatian children nowadays expect presents from Santa Claus (Djed Božićnjak literally, Grandfather Christmas), this was not always the case. In fact, the figure of a male giftgiver (originally referred to as Djed Mraz, Grandfather Frost) was largely popularized during the Communist regime although, as Rihtman-Auguštin points out, his appearance "in this part of the world" predates World War II ("Santa Claus in Transition" 112). Before that, gifts were brought by the Christ Child (commonly referred to as "baby Jesus"), born on Christmas Eve. In either case, the supernatural figure leaves gifts for children beneath the Christmas tree (cf. Rihtman-Auguštin, Christmas in Croatia). In Britain, gifts are also found in stockings hung over the mantelpiece. This custom is closely linked to the notion of Father Christmas coming down the chimney: according to legend, on one such occasion he dropped some gold coins which would surely have been lost had they not fallen into the stockings that were hung up to dry (Robbins and Charlton 15). The practice of hanging up stockings and filling them with presents is not widespread in Croatia ${ }^{[8]}$, which is probably why Crnković consistently expands Father Christmas's references to filling the children's stockings. Namely, while the original simply states that Father Christmas will fill the stockings (e.g. "I hope you will like your stockings this year"; Tolkien, FCL 16), the translation adds that they will be filled with presents (“[N]adam se da će vam pokloni u vašim čarapama biti po volji”/l hope the presents in your stockings will be to your liking; Tolkien, PDB 16). 
The British tradition of hanging up stockings is somewhat reminiscent of Croatian traditions linked to St. Nicholas' Day (celebrated on December 6): namely, before going to bed on December 5, children clean their boots and place them on the windowsill. If they were good, St. Nicholas will fill the boots with gifts (cf. Dragić). In many countries, St. Nicholas acted as the Christmas gift-giver before the arrival of Santa Claus/Father Christmas, who successfully substituted him in this role and took on many of his features (Rihtman-Auguštin, "Santa Claus in Transition" 112). In Croatia, both figures continue to exist and reward good children on different days, at the beginning (St. Nicholas) and towards the end of the holiday season (Father Christmas).

The traditions of filling stockings on Christmas Eve and filling boots on the eve of St. Nicholas are quite similar. In fact, the custom of hanging stockings was first associated with St. Nicholas and only later ascribed to Father Christmas (Gulevich 742). In his exploration of the figure of St. Nicholas within the Croatian hagiographic heritage, Marko Dragić mentions the legend about golden coins landing in the stockings hung up to dry, this time thrown by St. Nicholas, who climbed down the chimney to save the daughters of an impoverished official from prostitution (8). The links between gift-giving traditions related to St. Nicholas and those typical of (British) Christmas are also recognized by the translator of the $\mathrm{FCL}$, who brings them together in an interesting blend of foreignization and domestication:

(ST, example 1):

"I suppose after this year you will not be hanging your stockings any more" (Tolkien, FCL 43)

$$
\text { (TT, example 1): }
$$

"Bojim se da više nećete ostavljati čarape u prozoru" / I'm afraid you will no longer leave stockings on the windowsill (Tolkien, PDB 43)

Here, the foreign meets the domestic as the (British) tradition of hanging stockings over the mantelpiece before Christmas (the reference to stockings in the translated text) is mixed with the (Croatian) tradition of placing boots on the windowsill on the eve of St. Nicholas' Day (the reference to windowsills). 
Additional blending of domestication and foreignization is found in the translations of two holidays which immediately follow Christmas: Boxing Day and St. Stephen's Day, both celebrated on December 26. Being an unmatched element of culture, Boxing Day is translated descriptively as the second day of Christmas ("drugi dan Božića"; Tolkien, PDB 16; 20). On the two occasions in which it is mentioned in the text, St. Stephen's Day is translated differently: first descriptively (i.e. relying on foreignization) as the second day of Christmas ("drugi dan Božića"), and then by using the Croatian equivalent (domestication) "Stjepanje" (Tolkien, PDB 36).

A lengthy intratextual gloss is added to explain another holiday CSI - the identity of Father Christmas's Green Brother:

\section{(ST, example 2):}

Well, my dears, there is lots more I should like to say - about my Green Brother, and my father, old Grandfather Yule, and why we were both called Nicholas after the Saint (whose day is December sixth) who used to give secret presents, sometimes throwing purses of money through the window.

(Tolkien, FCL 17)

\section{(TT, example 2):}

E pa, eto, dragi moji, htio bih vam još mnogo toga ispričati - o svom ocu, i o svom starom Djedu Božićnjaku, i o svom zelenom bratu (koji dariva djecu u krajevima u kojima Božić pada u ljeto), i o tome zašto nas obojicu zovu i Sveti Nikola (čiji se dan slavi 6. prosinca), koji je potajice dijelio darove i kadikad bacao kroz prozor novčarke pune novca. / Well, my dears, there is lots more I should like to say - about my father, and about my old Grandfather Christmas, and about my Green Brother (who brings gifts to children living in areas where Christmas is celebrated during the summer season), and why we are both also called Saint Nicholas (whose day is celebrated on

December 6), who used to secretly give presents and sometimes throw purses full of money through the window. (Tolkien, PDB 17)

The translated sentence contains a considerable amount of new information, the most prominent being the added explanation about the Green Brother (this is the only intratextual gloss placed within brackets). The changed word order in the translated sentence also creates a closer link 
between Father Christmas and his Green Brother, making it clear that it is the two of them (and not Father Christmas and his Grandfather Yule) who are called Nicholas. Moreover, the TT mentions the full appellative of the saint, rather than just his name (which is the case in the ST).

\subsection{Explicitation}

The use of intratextual glosses is not limited to explanations of cultural customs. On the contrary, it often appears as part of explicitation, defined by Kinga Klaudy as "the technique of making explicit in the target text information that is implicit in the source text" (80). Klaudy distinguishes between four types of explicitation: 1) obligatory explicitation, dictated by the syntactic and semantic differences that exist between the target and source language; 2) optional explicitation, which occurs at the text-building and stylistic level; 3) pragmatic explicitation, which includes the addition of cultural explanations; and 4) translation-inherent explicitation, derived from the nature of the translation process (82-83) ${ }^{[9]}$ Utilizing Klaudy's terminology, Crnković's translation tactics may be specified as pragmatic and optional explicitation.

In addition to cultural explanations (pragmatic explicitation), the translation also features explanations of various elements the child readers may not be familiar with. This is the case with Aurora Borealis, which the TT elaborates on in an intratextual gloss:

\section{(ST, example 3):}

"The tap turning on the Aurora Borealis fireworks is still in the cellar of my old house" (Tolkien, FCL

9)

(TT, example 3):

"U podrumu moje stare kuće još se nalazi slavina iz koje se pušta Aurora Borealis, to vam je šareni zastor od polarne svjetlosti" / In the cellar of my old house, there is still a tap turning on the Aurora Borealis, that is a colorful curtain made of the Northern Lights (Tolkien, PDB 9).

Optional explicitation is manifested as the addition of various connective elements and explanatory 
structures that strengthen and highlight logical connections in the narrative. Consider the following examples:

$$
\text { (ST, example 4): }
$$

"I am more shaky than usual this year"; "I have tried to draw a picture of it; but I am too shaky to do it properly" (Tolkien, FCL 9)

\section{(TT, example 4):}

"Ove godine dršće mi ruka [my hand is shaking] još više nego prije"; "Pokušao sam to naslikati, ali mi se ruke previše tresu [my hands are too shaky] da bih to uradio kako treba" (Tolkien, PDB 9).

In both examples, the TT contains additional, explicit references to the hand as the shaky part of Father Christmas's body, thus underscoring the fact that it is the cause of the shaky handwriting. A similar strengthening of logical connections is found in the following examples, which add references to wind and the light of the comet respectively:

\section{(ST, example 5):}

"[O]ne very windy day last November my hood blew off and went and stuck on top of the North

$$
\text { Pole" (Tolkien, FCL 6) }
$$

$$
\text { (TT, example 5): }
$$

"[J]ednog vjetrovitog dana u mjesecu studenom vjetar mi je odnio kapu s glave [the wind blew my cap off my head] i zataknuo je na vrh motke na Sjevernom polu" (Tolkien, PDB 6)

$$
\text { (ST, example 6): }
$$

"[T]his week I have hired a comet to do my packing by ..." (Tolkien, FCL 10)

$$
\text { (TT, example 6): }
$$

"[O]vog sam tjedna unajmio i jedan komet da mi svijetli [hired a comet to shine for me] dok pakiram darove ..." (Tolkien, PDB 6) 
The translator also adds reminders to previous episodes in the text. For instance, when Father Christmas refers to the incident in which the Polar Bear opened the tap and let off a two-year supply of the Northern Lights, he simply says: "Nothing as bad as letting off all the lights" (Tolkien, FCL 12). The translation is more elaborate, providing additional details to remind the reader about this event: "Nije doduše ništa onako strašno kao onda kad je iz slavine pustio sva ona polarna svjetla" / Nothing as bad as that time when he let off all those Northern Lights from the tap (Tolkien, PDB 12).

\title{
3.3. Units of Measurement
}

While foreignization is the dominant strategy when it comes to translating Christmas-related CSIs, domestication is utilized in the case of measurement units. The TT thus converts feet, inches, miles, and pounds into meters, centimeters, kilometers, and kilograms. Although translations (or rather, orthographic adaptations) of these terms do exist in Croatian (e.g. mile - milja, inch - inč), the translator (perhaps assuming that the target audience will not be familiar with foreign measurement units) substitutes them with their Croatian equivalents, as seen in the following examples:

\author{
(ST, example 7): \\ "nearly six feet of snow" (Tolkien, FCL 16)
}

(TT, example 7):

"snijeg je bio gotovo dva metra [two meters] visok" (Tolkien, PDB 16)

$$
\text { (ST, example 8): }
$$

"there has not been even a smell of Goblin for 200 miles round" (Tolkien, FCL 30)

(TT, example 8):

"nije bilo ni traga od goblina u krugu od 350 kilometara [350 kilometres]" (Tolkien, PDB 30) 


\section{(ST, example 9):}

"with nearly 100 lbs. of gunpowder" (Tolkien, FCL 43)

(TT, example 9):

"uz pomoć gotovo 50 kilograma [50 kilograms] baruta" (Tolkien, PDB 43)

\subsection{Names}

Consideration for the child reader is evident in the translation of names as well. Proper names of the child recipients are retained in their original form, while the names of fictional characters are translated. Retaining the names of the British children - the original addressees of the letters serves as another reminder to "young readers that they are reading a story set in another country" (Lathey 44), thus confirming the translator's awareness of the impossibility of domesticating the text to a greater degree.

When it comes to the translation of fictional names, the most interesting case is that of the (North) Polar Bear, whose name in translation appears in two almost interchangeable forms: the full name Sjeverni Bijeli Medvjed (the North Polar Bear) and its diminutive form Bijeli Medo - literally the white (Polar) teddy. Rooted in the sentimentalizing approach to children's literature (Stolt 75-77), the diminutive form Medo may be intended to make the character "cuter" and more endearing to the target child reader (Van Coillie 134). This translation choice is guided by what Jan Van Coillie identifies as the emotional function of a name, which "speaks to the emotions and enriches them" (124), since the word Medo, often used in reference to teddy bears, evokes positive sentiments and fondness for its bearer.

Initially, it seems that the terms Sjeverni Bijeli Medvjed and Bijeli Medo are used as equivalents for the North Polar Bear and Polar Bear respectively. However, as the text unfolds, Bijeli Medo is used with increasing frequency, becoming the standard term of reference to the character, regardless of the appellative used in the ST. This is perhaps meant to reflect the changing attitudes of Father Christmas himself, who goes from constantly complaining about the Bear's antics to admitting he is fond of him and could not get by without him. The emotional aspect is further highlighted in several 
instances (e.g. in the 1932 letter) in which the TT refers to the Polar Bear as "naš Medo" (literally, our Bear; Tolkien, PDB 23). The possessive adjective is absent from the ST.

\subsection{Style}

The epistolary nature of Tolkien's text allows for a more informal and conversational tone of narration, which is additionally highlighted in Crnković's translation. This is most evident in his stylistic choices, especially the use of various colloquial words and expressions, such as "sprdati se" (Tolkien, PDB 12) to translate the phrase "make fun of" (instead of the more standard ismijavati or rugati se), "smazati" (20) to translate "eat" (instead of jesti or pojesti), or "zucnuti" (23) to translate "say" (instead or reći, kazati, prozboriti, etc.). In a similar vein, Crnković opts for various vivid idiomatic phrases, even in cases when the same flourish is absent from the ST. Consider the following:

(ST, example 10):

"but that did not stop him laughing" (Tolkien, FCL 14)

(TT, example 10):

"To ga ipak nije spriječilo da se smije kao lud brašnu" / That did not prevent him from laughing like a crazy person laughs at flour (Tolkien, PDB 14)

(ST, example 11):

"and has been well ever since" (Tolkien, FCL 16)

(TT, example 11):

"i odonda je opet zdrav kao dren" / and has been as healthy as dogwood ever since (Tolkien, PDB 16)

(ST, example 12):

"SAY NO MORE: I ENJOYED IT IMMENSELY!" (Tolkien, FCL 28; all caps in the original) 
(TT, example 12):

"ŠTA DA SE PRIČA: UŽIVO SAM KO PRASE" / WHAT CAN I SAY: I ENJOYED IT LIKE A PIG (Tolkien, PDB 16; all caps in the original)

The colloquiality of the phrases not only adds to the overall conversational tone but also lends it a touch of humor and helps naturalize the narration. Some of the words and phrases used in the text are slightly archaic, regional, or simply rarely used in day-to-day communication, which creates the impression that the impossibly old Father Christmas (he claims to be "1925 years old"; Tolkien, FCL 6) belongs to a different time.

\section{Concluding Remarks}

As numerous scholars have pointed out, translation is "always influenced by what is translated by whom and for whom, and when, where, and why" (Oittinen, Translating for Children 12). However, in some cases - such as PDB - the issue of "for whom" becomes particularly pertinent. As the analysis presented above demonstrates, Zlatko Crnković's translation of Tolkien's children's book into Croatian displays a strong target orientation (cf. Nord 194) as the majority of translation choices are guided by the perceived interests and needs of the intended child audience. Putting the child reader first, the translator does not hesitate to deviate from the ST to some degree, often modifying and expanding it for the sake of comprehension. The fact that many of his choices are somewhat questionable from the point of view of the so-called fidelity to the ST, but are quite satisfactory from the point of view of style and language, suggests that his primary goal is to create a coherent and readable text in the target language.

Modifications and alterations are evident at both the stylistic and the level of content. Generally speaking, Crnković is guided by two main principles of translating for children described by Zohar Shavit: adding new information and modifying the text "in order to make it appropriate and useful to the child," and adapting the language (both in a stylistic and syntactic sense) "to the child's level of comprehension and ... reading abilities" (172). Aware that the ST cannot be fully domesticated, Crnković constantly shifts between domestication and foreignization: while some CSIs (primarily 
units of measurement) are replaced with their Croatian equivalents, others are retained in the original form and explained through intratextual glosses. Both strategies are intended to make the text more accessible and comprehensible to the target audience. Furthermore, the translator uses colloquial and idiomatic language to create a distinctive narratorial voice for Father Christmas. Extensively using explicitation, the TT fills in the gaps the ST leaves to readers and highlights much of the logical connections and other implicit content. In that sense, Crnković's text may be described as a communicative translation: one which aims to preserve the meaning of the original but at the same time tries to make it as comprehensible, simple, and natural as possible (cf. Newmark 45-47).

Future research into the Croatian translation of the FCL may examine other aspects of the TT (e.g. the syntactic level) or explore the role the publishing house played in this process, especially with regards to the selection of the FCL (rather than the LFC) as the ST, as well as the decision not to translate the intraiconic text. Although Crnković's concern for the child reader is present in PDB, this may not be the case with his other translations. Future research may, therefore, take into consideration his other translations of children's literature (e.g. Tolkien's Roverandom or The Hobbit) as well as those for adults, in order to determine possible differences predicated on the type of the implied audience (adult, child, cross-over).

\section{Works Cited}

Alujević, Maja. “O blagdanu Svete Lucije.” Ethnologica Dalmatica, vol. 15, no. 1, 2006, pp. 107-16. Artamonova, Maria. “'Minor' Works.” A Companion to J.R.R. Tolkien, edited by Stuart D. Lee, Wiley Blackwell, 2014, pp. 189-201.

Atherton, Mark. There and Back Again: J.R.R. Tolkien and the Origins of The Hobbit. I. B. Tauris, 2012.

Bador, Damien. "From The Silmarillion to The Hobbit and Back Again. An Onomastic Foray." The Hobbit and Tolkien's Mythology. Essays on Revisions and Influences, edited by Bradford Lee Eden, McFarland \& Company, Inc., 2014, pp. 97-112. 
Becher, Viktor. "Abandoning the Notion of 'Translation-Inherent' Explicitation: Against a Dogma of Translation Studies." Across Languages and Cultures, vol. 11, no. 1, 2010, pp. 1-28.

Brewer, Derek. “Father's Fantasies.” Times Literary Supplement, 1976, p. 1239.

Cocargeanu, Dana. "The Adventures of Peter Rabbit in Romania: Translation Challenges and Strategies." International Research in Children's Literature, vol. 7, no. 2, 2014, pp. 198-212.

Croft, Janet Brennan. "Beyond The Hobbit: J.R.R. Tolkien's Other Works for Children." World Literature Today, vol. 78, no. 1, 2004, pp. 67-70.

Dragić, Marko. "Sveti Nikola - biskup u hagiografskoj baštini Hrvata." Ethnologica Dalmatica, vol. 22, no. 1, 2015, pp. 5-42.

Franco Aixelá, Javier. "Culture-Specific Items in Translation." Translation, Power, Subversion, edited by Román Alvarez and M. Carmen-África Vidal, Multilingual Matters, 1996, pp. 52-78.

Gambier, Yves. "Translation strategies and tactics". Handbook of Translation Studies. Volume 1, edited by Yves Gambier and Luc van Doorslaer, John Benjamins Publishing Company, 2010, pp. 412-18.

Gulevich, Tanya. Encyclopedia of Christmas and New Year's Celebrations. 2nd ed., Omnigraphics, 2003.

Haramija, Dragica. "Književna djela Ivane Brlić-Mažuranić u slovenskom prijevodu." "Šegrt Hlapić". Od čudnovatog do čudesnog, edited by Berislav Majhut, Smiljana Narančić Kovač, and Sanja Lovrić Kralj, Hrvatska udruga istraživača dječje književnosti, Ogranak Matice hrvatske Slavonski Brod, 2015, pp. 369-80.

Hiley, Margaret, and Frank Wienreich, eds. Tolkien's Shorter Works: Proceedings of the 4th Seminar of the Deutsche Tolkien Gesellschaft \& Walking Tree Publishers Decennial Conference. Walking Tree Publishers, 2008.

Honegger, Thomas, ed. Tolkien in Translation. Walking Tree Publishers, 2003.

Hostetter, Carl F. "Tolkienian Linguistics: The First Fifty Years." Tolkien Studies: An Annual Scholarly Review. Volume IV, edited by Douglas A. Anderson et al., West Virginia University Press, 2007, pp. 1-46. 
Hyde, Paul Nolan. "A Philologist at the North Pole: J.R.R. Tolkien and The Father Christmas Letters." Mythlore, vol. 15, no. 1, 1988, pp. 23-27.

Hynes, Gerard. "'Beneath the Earth's Dark Keel': Tolkien and Geology." Tolkien Studies: An Annual Scholarly Review. Volume IV, vol. 9, 2012, pp. 21-36.

Klaudy, Kinga. "Explicitation." Routledge Encyclopedia of Translation Studies, edited by Mona Baker, Routledge, 2000, pp. 80-84.

Klingberg, Göte. Children's Fiction in the Hands of the Translators. Liber/Gleerup, 1986.

Krieg, Martha, and Laurence Krieg. "The Father Christmas Letters." Mythlore, vol. 4, no. 2, 1976, pp. 24-25.

Lathey, Gillian. Translating Children's Literature. Routledge, 2016.

Machata, Martin. “O prijevodu i prevođenju Čudnovatih zgoda šegrta Hlapića na slovački.” Libri \& Liberi, vol. 2, no. 2, 2014, pp. 209-24.

Munday, Jeremy. Introducing Translation Studies: Theories and Applications. Routledge, 2011.

Narančić Kovač, Smiljana. "Tales of Long Ago as a Link between Cultures." The ESSE Messenger, vol. 25 , no. 1,2016 , pp. 93-107.

Narančić Kovač, Smiljana, and Ivana Milković. "Tko je ukrao kolačiće: intertekstualna sastavnica Aličinih pustolovina u Čudozemskoj u hrvatskim izdanjima." Redefiniranje tradicije: dječja književnost, suvremena komunikacija, jezici i dijete, edited by Ante Bežen and Berislav Majhut, Učiteljski fakultet Sveučilišta u Zagrebu/Europski centar za napredna i sustavna istraživanja, 2011, pp. 223-40.

Newmark, Peter. A Textbook of Translation. Prentice Hall, 1998.

Nikolajeva, Maria, and Carole Scott. How Picturebooks Work. Garland Publishing, Inc., 2001. Nord, Christiane. "Proper Names in Translations for Children: Alice in Wonderland as a Case in Point." Meta: Journal Des Traducteurs / Meta: Translators' Journal, vol. 48, no. 1-2, 2003, pp. 182-96. 
Oittinen, Riitta. "No Innocent Act. On the Ethics of Translating for Children." Children's Literature in Translation. Challenges and Strategies, edited by Jan Van Coillie and Walter P. Verschueren, St. Jerome Publishing, 2006, pp. 35-45.

Oittinen, Riitta. Translating for Children. Garland Publishing, Inc., 2000.

Organ, Michael. “Tolkien's Japonisme: Prints, Dragons, and a Great Wave.” Tolkien Studies: An Annual Scholarly Review. Volume IV, vol. 10, 2012, pp. 105-22.

Pascua-Febles, Isabel. "Translating Cultural References. The Language of Young People in Literary Texts." Children's Literature in Translation. Challenges and Strategies, edited by Jan Van Coillie and Walter P. Verschueren, St. Jerome Publishing, 2006, pp. 111-21.

Reiss, Katharina. "Zur Übersetzung von Kinder- und Jugendbüchern: Theorie und Praxis." Lebende Sprachen, vol. 27, 1982, pp. 7-13.

Rihtman-Auguštin, Dunja. Christmas in Croatia. Golden marketing, 1997.

Rihtman-Auguštin, Dunja. "Santa Claus in Transition." Narodna umjetnost: Croatian Journal of Ethnology and Folklore Research, vol. 32, no. 1, 1995, pp. 107-22.

Robbins, Maria, and Jim Charlton. A Christmas Companion. Recipes, Traditions and Customs from around the World. Perigree Books, 1989.

Scull, Christina. "The 'Father Christmas' Letters." Too Many Books and Never Enough, the Weblog of Wayne G. Hammond \& Christina Scull, 6 November 2012, wayneandchristina.wordpress.com/2012/11/06/the-father-christmas-letters-4/. Accessed 10 Dec. 2017.

Scull, Christina, and Wayne G. Hammond. The J.R.R. Tolkien Companion \& Guide. Houghton Mifflin Company, 2006.

Shavit, Zohar. "Translation of Children's Literature as a Function of Its Position in the Literary Polysystem." Poetics Today, vol. 2, no. 4, 1981, pp. 171-79.

Stolt, Birgit. "How Emil Becomes Michael: On the Translation of Children's Books." Translation of Children's Literature, edited by Gillian Lathey, Multilingual Matters, 2006, pp. 67-83. 
Swank, Kris. "The Hobbit and The Father Christmas Letters." Mythlore, vol. 32, no. 1, 2013, pp. $127-44$.

Šmidt Pelajić, Iris. "Kako likove romana o šegrtu Hlapiću zovu čitatelji njemačkog govornog područja." "Šegrt Hlapić". Od čudnovatog do čudesnog, edited by Berislav Majhut, Smiljana Narančić Kovač, and Sanja Lovrić Kralj, Hrvatska udruga istraživača dječje književnosti, Ogranak Matice hrvatske Slavonski Brod, 2015, pp. 349-67.

Tolkien, J.R.R. Pisma Djeda Božićnjaka. Translated by Zlatko Crnković, Algoritam, 2002.

Tolkien, J. The Father Christmas Letters. Edited by Bailie Tolkien, Houghton Mifflin Company, 1976.

Toury, Gideon. Descriptive Translation Studies - and Beyond. John Benjamis Publishing Company, 2012.

Turner, Allan. Translating Tolkien: Philological Elements in The Lord of the Rings. Peter Lang, 2005.

Van Coillie, Jan. "Character Names in Translation. A Functional Approach." Children's Literature in Translation. Challenges and Strategies, edited by Jan Van Coillie and Walter P. Verschueren, St. Jerome Publishing, 2006, pp. 123-39.

Venuti, Lawrence. The Translator's Invisibility. A History of Translation. Routledge, 1995.

Weaver, Warren. Alice in Many Tongues: The Translations of "Alice in Wonderland." University of Wisconsin Press, 1964.

Zalar, Diana. Potjehovi hologrami: studije, eseji i kritike iz književnosti za djecu i mladež. Alfa, 2014.

Zima, Dubravka. "Ivana Brlić-Mažuranić, članstvo u Akademiji i Nobelova nagrada." Libri \& Liberi, vol. 3, no. 2, 2014, pp. 239-62. 
[1] This work has been fully supported by the Croatian Science Foundation under the project BIBRICH (UIP-2014-09-9823). The author would like to gratefully acknowledge the help of Smiljana Narančić Kovač, who read an early version of the manuscript and provided valuable feedback. The author would also like to thank Matúš Mišík for his generous support and assistance with all the formal and "technical" aspects of the paper.

[2] Brlić-Mažuranić is perhaps best known to international readers as the author of the children's novel Čudnovate zgode šegrta Hlapića (1913; translated into English in 1971 by Theresa Mravintz and Branko Busar as The Brave Adventures of a Shoemaker's Boy) and the collection of fairy tales Priče iz davnine (1916; translated into English in 1924 by Fanny S. Copeland as Croatian Tales of Long Ago).

[3] Abbreviations used in this paper include the following: CSI (culture-specific item), FCL (Father Christmas Letters), LFC (Letters from Father Christmas), LOTR (The Lord of the Rings), PDB ( Pisma Djeda Božićnjaka), SC (source culture), ST (source text), TC (target culture), and TT (target text).

[4] According to the list provided in Scull and Hammond's The J.R.R. Tolkien Companion and Guide, both the FCL and different editions of the LFC have been translated into numerous languages. However, as with the rest of Tolkien scholarship, the study of translations of the British author's writings has also been primarily focused on his "major" works - predominantly LOTR (see, for instance Honegger; Turner).

[5] Along with the FCL, these include Roverandom (1925-1927), Farmer Giles of Ham (1926-1938), and Mr Bliss (1932/33).

[6] For an extensive overview of the book's publishing history and comparisons of the contents of different editions, see Scull.

[7] Even the scholarly works explicitly aimed at expanding the discussion on Tolkien beyond The Hobbit and LOTR typically overlook the FCL/LFC (e.g. Hiley and Wienreich).

[8] In some regions of Croatia, stockings play a role in the gift-giving customs of St. Lucija: the 
saint rewards good children by leaving gifts in the stockings placed beneath their pillows (Alujević 112-13).

[9] For a critique of some aspects of Klaudy's classification, see, for instance, Becher.

\section{(c) (i) (9)}

Creative Commons Attribution-NonCommercial-NoDerivatives 4.0 International License 